\title{
Территории опережающего развития Хабаровского края в аспекте «зелёного» роста
}

\author{
Зоя Мирзеханова, Анастасия Кольцова* \\ Институт водных и экологических проблем ДВО РАН, г. Хабаровск, Россия
}

\author{
Информация о статье \\ Поступила в редакиию: \\ 27.06.2019 \\ Принята \\ к опубликованию: \\ 22.11.2019
}

УдК 502.1(571.6)

JEL Q56, R11

\section{Ключевье слова:}

зелёная экономика, зелёный рост, территория опережающего развития, Хабаровский край

\section{Keywords:}

green economy, green growth, the Territory of advanced development, Khabarovsk territory

\begin{abstract}
Аннотация
В статье представлено авторское видение экологоэкономической ситуачии в рамках формирования территорий опережающего развития в Хабаровском крае с позиции современной модели «зелёной экономики». Проведённый анализ показал, что выбранное направление развития демонстрирует усиление сырьевой направленности, однако в южных регионах есть и положительные тенденции в сторону приоритетных отраслей «зеленой экономики». В пределах Хабаровского края более $70 \%$ проектов соответствуют приоритетным отраслям, но даже в проектах связанных с экологоориентированными отраслями без внимания оставлены вопросы «озеленения» экономики.
\end{abstract}

\section{Territories of Advanced Development in the Khabarovsk Territory in Terms of Green Growth}

Zoya Mirzekhanova, Anastasiya Koltsova

\section{Abstract}

Territories of advanced development are special industrial zones with special legal regime for attracting investments. It is one of the modern facilitating instruments of the Russian Far East policy. The main objective of the article is to determine how this modern policy corresponds to the global trends in the field of the green economy. Green economy is an economic paradigm which promotes low carbon growth, efficient utilization of natural resources and assets.

Far East region needs a sustainable economic growth that does not result in the natural resources depletion and environment damaging. The principal trends within the northern territories of advanced development are stated to be raw industries, mainly branches of oil and gas chemistry. However, in the southern regions of the Far East there are also positive trends towards the priority of green economy industries. In Khabarovsk Krai more than $70 \%$ of the projects relate to the priority industries of the green economy and only $2 \%$ of the projects are aimed at mining. Unfortunately, even in the projects connected with the ecofriendly industries issues of using green economy principles are disregarded. Under the present circumstances, eco-technology and innovations will be critical in providing opportunities for the

\footnotetext{
* Автор для связи: never_give_up@mail.ru

DOI: https://dx.doi.org/10.24866/2311-2271/2019-4/23-34
} 
ecological balance recovery, resulting in a more eco-friendly, sustainable and diversified regional economy. In the context of green economy special attention should be paid to such industries as waste recycling, tourism, power, agriculture, forestry, fishing and high-tech industries. It has been found that to achieve high social, economic and environmental efficiency it is expedient to expand territories of advanced development according to the green standards.

\section{Введение}

Территория опережающего развития (далее - ТОР) - часть территории субъекта Российской Федерации, в пределах которой устанавливается особый правовой режим для привлечения инвестиций с целью обеспечения ускоренного социально-экономического развития и создания комфортных условий для жизнедеятельности населения [1]. Этот инструмент оздоровления экономической ситуации на Дальнем Востоке России используется уже несколько лет. Результаты как впечатляют размахом действия, так и вызывают определённую тревогу в части экологических аспектов формирования и развития таких территорий. По данным Минвостокразвития, к концу 2018 г. в 8-и дальневосточных субъектах создано 18 ТОР, заключено 192 соглашения с резидентами об осуществлении деятельности в их пределах. Планируемый объем инвестиций составляет 2 трлн 132 млрд руб., общее количество создаваемых рабочих мест 38140 [2]. Сложившаяся ситуация по вводу в действие проектов имеет устойчивый тренд к удвоению результатов. Согласно информации АО «Корпорация развития Дальнего Востока», в 2015 г. завершённых объектов было 2, в 2016 г. их насчитывалось 24, в 2017 г. эта величина составила 57 объектов, в 2018 г. 177.

Учитывая относительно слабую изученность региона, привлекательные преференции экономического характера, перспективы создания новых точек активизации хозяйственной деятельности вполне очевидны. Такому активному прессу на территорию Дальнего Востока должна противостоять адекватная ожидаемому воздействию региональная экологическая политика, которой, к сожалению, на данный момент нет. Экономические показатели в контексте обозначенных законом льгот наиболее полно прорабатываются, при определённой критике отдельные из них могут претендовать на завершённость [3]. Социальные и демографические показатели сведены в большинстве случаев к ожидаемой оценке увеличения рабочих мест. Что же касается экологических параметров функционирования ТОР в целом, отдельных производств в их пределах, специфики ресурсопотребления и формирования отходов, разработки компенсационных мер и т.д. - все это оставлено за рамками внимания. Дальневосточные ТОР не одиноки в ориентации и расстановке приоритетов: жёсткие экологические требования для резидентов не предусмотрены и в пределах ТОР других регионов страны. Создаётся ситуация, что самый главный приоритет в развитии регионов России - это количество резидентов, а экологическая составляющая там занимает далеко не первое место [4].

Между тем, именно этот фактор развития экономики на мировом уровне и задекларированном национальном уровне признана доминирующей. Ещё на конференции в Рио (1992 г.) было доказано, что традиционная модель экономического роста развитых стран во многом исчерпала себя, и она не может быть предложена для других стран в качестве образца. Западная модель уже никого не удовлетворяет. Общепризнанно, что, сложившаяся модель развития и соответствующий характер производства и потребления не являются устой- 
чивыми для развитых стран и не могут стать эталоном для развивающихся [5-9].

Ненадёжность современной модели развития подтверждается динамикой деградации природных систем и все резче проявляющимися ресурсноэкологическими проблемами. Установлено, что за 70-летний предшествующий период более $60 \%$ экосистем в мире были трансформированы в связи с активизацией ресурсопотребления, обеспечив тем самым рост мировой экономики более, чем в 5 раз [10]. Рост численности населения до 9 млрд человек, нуждающихся в продуктах питания, воде и энергии, генерирующих более 13,1 млрд тонн отходов, на фоне беспрецедентной трансформации природных комплексов вынуждает по-новому оценивать возможности и перспективы развития мировой цивилизации. Усугубляет ситуацию возрастающий тренд ресурсопотребления не соответствующий возможностям ресурсовосстановления. Например, чтобы обеспечить растущее население планеты продуктами питания и энергией, необходимо повышение производительности в сельском хозяйстве в среднем на $2 \%$ в год. Однако, современные технологии в сельскохозяйственном секторе уже предопределяют потребление более 70\% мировых ресурсов питьевой воды, сельскохозяйственное производство уже сегодня обеспечивает 13\% мирового объёма выбросов парниковых газов [11]. Нарастающие объёмы отходов, из которых утилизируется лишь около $25 \%$, усугубят экологическую обстановку для 70\% жителей планеты [12]. Мировой спрос на энергию вырастет на 36\% в течение 2008-2035 гг. [13]. Если развитие будет осуществляться по традиционному сценарию, потребуется увеличение потребления природных ресурсов для обеспечения растущего населения Земли к 2050 г. в объёме, эквивалентном $2 / 3$ сегодняшнего объёма ресурсов планеты $[14,15]$. С такой нагрузкой планета может не справиться. Экологические аргументы в пользу изменения или, по крайней мере, кардинального преобразования действующей модели становятся всё весомее. На повестке дня жёсткие экологические ограничения в развитии мировой экономики, зафиксированные в новой модели, названной «зелёной», усиливая тем самым значимость экологической составляющей.

Мировое сообщество признало модель «зелёной экономики» (далее - 3Э) наиболее соответствующей текущим потребностям как в плане экономических, так и экологических требований. С момента саммита G20 в Лос-Кабосе (2012 г.), где эта модель была признана ведущими странами в виде стратегической цели развития мирового сообщества, она становится своеобразной идеологией и мировоззрением. Концептуальные основы модели $3 Э$ выстроены как гармоничное продолжение концепции устойчивого развития, но использование прилагательного «зеленый» подчёркивает критическую важность экологической устойчивости для новой экономики [16].

Тенденции «озеленения» экономического развития Хабаровского края в условиях политики развития ТОР

Несмотря на то, что законопроект, регулирующий создание и функционирование ТОР, напрямую не затрагивает вопросов «озеленения» экономики, развитие этих зон не может проходить вразрез новой мировой стратегии в применении ориентиров, обозначенных в модели $3 Э$ и принятых Россией ${ }^{1}$. Безус-

\footnotetext{
1 Основы государственной политики в области экологического развития России на период до 2030 года (утв. Президентом РФ от 30 апреля 2012 г.), Стратегия экологической безопасности Российской Федерации
} 
ловно, в любой программе развития территории есть как плюсы, так и минусы. Например, площадки ТОР в пределах южных регионов Дальнего Востока обеспечивают компактное расположение производств в уже освоенных зонах. Формирование производственных мощностей в специальных зонах вблизи жилых районов или непосредственно в их пределах позволяет уменьшить расходы, связанные с обслуживанием инфраструктуры, экономить производственные и природные ресурсы, но создают проблемы в обеспечении комфортного проживания местному населению, усугубляют ситуацию с ресурсопотреблением и обострением уже сложившихся экологических проблем. Увеличение нагрузки при концентрации производственных мощностей предполагает необходимость использования исключительно зелёных технологий, обеспечивающих соблюдение ресурсно-экологических регламентов.

В то время как в большинстве развитых стран и в некоторых регионах России уже запущены различные механизмы, стимулирующие развитие «зелёных» технологий, на Дальнем Востоке этот процесс только начинается. Основным фактором, сдерживающим этот процесс, является устойчивая приверженность экономики региона к экспортно-сырьевой направленности, что обусловлено спецификой предшествующих периодов развития и заинтересованностью в сырье ближайших соседей - стран Азиатско-Тихоокеанского региона в настоящее время $[17,18]$. Тренд сохранения привычной сырьевой ориентации экономики очевиден и в условиях реализуемой политики ТОР (рис. 1).

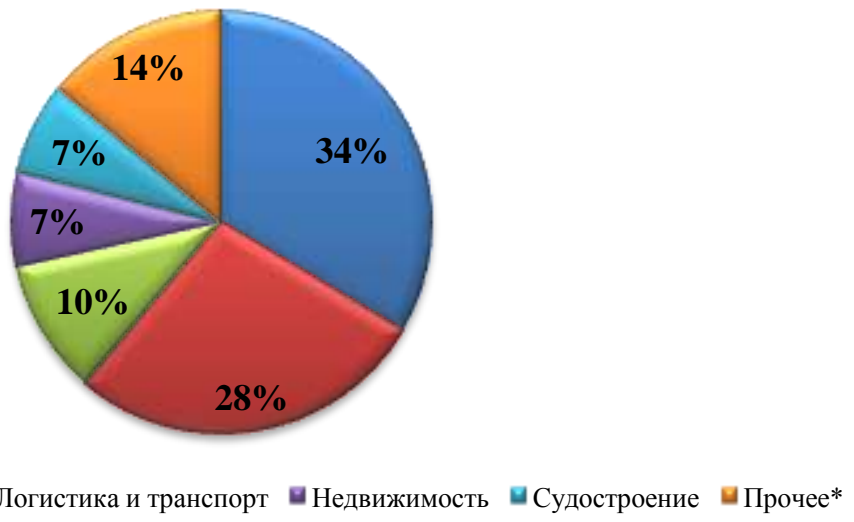

Puc.1. Распределение инвестиций по отраслям ТОР на Дальнем Востоке на конец 2018 г.

Примечание: * - в т.ч. сельское хозяйство, сфера услуг, туризм, производство пищевых продуктов, рыбная промышленность, лесная промышленность, машиностроение металлургия, горнорудная, алмазная промышленность, энергетика, медицина и т.д.

Источник: составлено авторами на основе $[17,18]$

Так, 72\% всех инвестиций (2028 млрд руб.), направленных в ТОР, связаны с развитием нефтегазовой промышленности и транспортно-логистического сектора, обеспечивающего преимущественно экспорт сырья. Надежды, возлагаемые на новую модель развития региона, обусловлены, в первую очередь, отказом (или хотя бы ослаблением значимости) от сложившейся сырьевой мо-

на период до 2025 г., утвержденная Указом Президента РФ от 19 апреля 2017 г. N 176. План действий по реализации Основ государственной политики в области экологического развития РФ на период до 2030 г., утвержденный распоряжением Правительства РФ от 18 декабря 2012 г. N 2423-p (Система ГАPAHT: http://base.garant.ru/70169264/\#ixzz5aZX1dDXF) 
дели. Не для всех дальневосточных регионов эти ожидания имеют реальную основу: формирование ТОР в северных субъектах традиционно основывается на инвестиционной привлекательности преимущественно минеральносырьевых отраслей. Однако для южных регионов потенциал преобразования территориально-отраслевой структуры хозяйства в направлении расширения спектра производства, в том числе и в сторону менее экологозатратных производств, очевиден.

Рассматривая эффективность формирования и функционирования ТОР в контексте соответствия требованиям модели ЗЭ, где приоритеты отведены сельскому, лесному, водному хозяйствам, рыболовству, ЖКХ, энергетике, обрабатывающей промышленности, туризму, транспорту, утилизации и переработке отходов, следует отметить широкий спектр потенциально реализуемых возможностей для региона. В рамках отмеченных секторов выделены ведущие направления 3Э: в энергетике - постепенный переход к возобновляемым источникам энергии и энергоэффективность в производстве и ЖКХ; в сельском хозяйстве - органическое земледелие, использование отходов в качестве вторичных ресурсов в промышленности и ЖКХ, сохранение и эффективное управление экосистемами в части сохранения экосистемных услуг и т.д. Рассмотрим на примере ТОР Хабаровского края основные тенденции их формирование в контексте обозначенных ориентиров модели $3 Э$.

Для Хабаровского края, занимающего третье место по объёму привлекаемых на Дальний Восток инвестиций, все вышеперечисленные сегменты хозяйственной деятельности имеют место быть. Но экологическая эффективность проводимой политики пока не позволяет однозначно утверждать о выполнении требований $3 Э$ в преобразовании территориально-отраслевой структуры экономики. Проведённый анализ основных тенденции современного развития ТОР в Хабаровском крае, на первый взгляд, показывают более оптимистичные результаты, нежели в целом по региону. Первые территории с особыми условиями деятельности - ТОР «Хабаровск» и ТОР «Комсомольск» - были созданы ещё в 2015 г., в 2017 г. к ним присоединилась ТОР «Николаевск». За столь недолгий период времени удалось достичь немалых результатов: резидентами фактически осуществлены инвестиции на сумму порядка 13 млрд руб., при этом создано более 1900 новых рабочих мест (рис. 2).

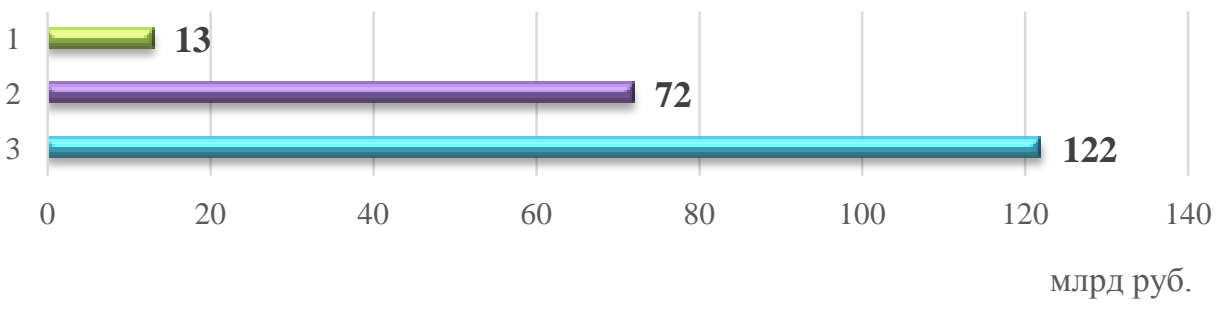

Рис.2. Планируемые и фактически реализованные объёмы инвестиций ТОР в Хабаровском крае по состоянию на конец 2018г.

Примечание: 1 - реализованные инвестиции; 2 - инвестиции по подписанным соглашениям; 3 планируемые инвестиции

Источник: составлено авторами

Отраслевая структура проектов ТОР Хабаровского края довольно разнообразна и представлена различными направлениями (рис.3). 


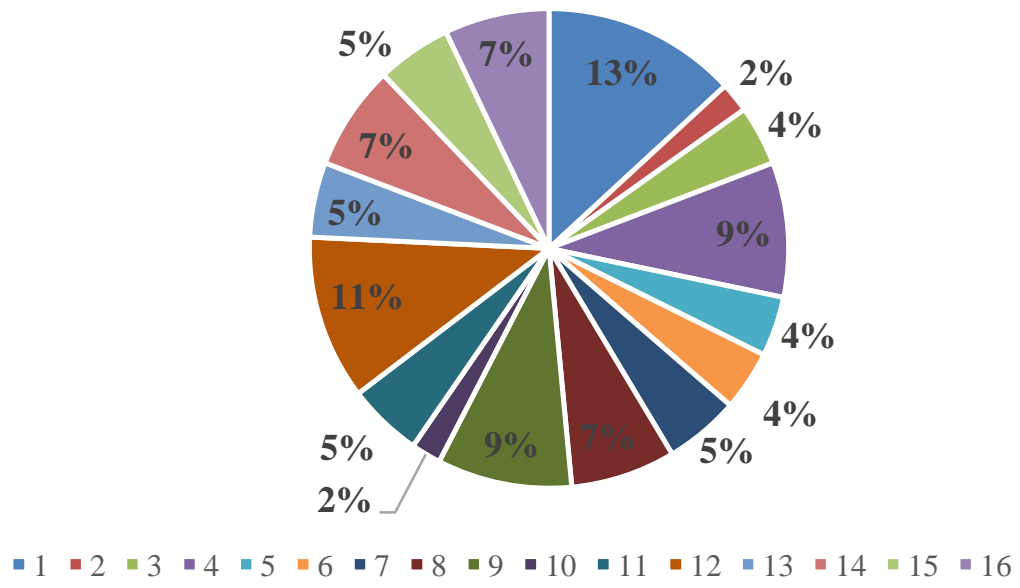

Puc. 3. Отраслевая структура проектов ТОР Хабаровского края (по состоянию на конец 2018г.)

Примечание: 1 - металлургическое производство; 2 - обработка древесины и производство изделий из дерева; 3 - производство электрического оборудования; 4 - производство пищевых продуктов; 5 - производство химической продукции; 6 - производство резиновых и пластмассовых изделий; 7 - производство транспортных средств и оборудования; 8 - строительство и производство строительных материалов; 9 - обработка отходов и вторичное производство; 10 - добыча полезных ископаемых; 11 - сельское хозяйство; 12 - транспорт и связь; 13 - туризм; 14 - предоставление коммунальных и пр. услуг для бизнеса; 15 - деятельность в области информационных технологий; 16 - рыболовство и рыбоводство

Источник: составлено авторами

Доля проектов по развитию ресурсосберегающих отраслей составляет порядка $30 \%$, в то же время количество проектов, связанных с добычей полезных ископаемых низкое, занимая лишь $2 \%$ в общем числе проектов. В целом по ДФО этот показатель составляет 7\%, а для северных субъектов округа достигает 60-80\%. Следовательно, с точки зрения экологичности изменения отраслевой структуры хозяйства ситуация в крае выглядит более обнадёживающей, чем в целом по ДФО. Значительная доля проектов ТОР (порядка 70\%) соответствует экологически значимыми отраслям, обозначенным в модели 3Э. Проанализируем, какие попытки по внедрению зелёных инноваций предпринимаются в осуществляемых проектах ТОР в пределах Хабаровского края.

Как уже отмечалось, для региона особую значимость имеет уход от сырьевых проектов. Более $30 \%$ объектов ТОР в Хабаровском крае ориентированы на развитие предприятий высокотехнологичных отраслей, в которых производится продукция с высокой долей добавленной стоимости. Одним из примеров успешной реализации инновационного производства является промышленная площадка «Авангард» в ТОР «Хабаровск». Площадка, обладающая высокотехнологичным потенциалом и всей необходимой инфраструктурой, была создана по инициативе ООО «ЭнергоИмпульс+» и уже впоследствии была причислена к ТОР «Хабаровск». ООО «Энерго-Импульс+» является одним из крупнейших на Дальнем Востоке производителей электротехнического оборудования, а в пределах созданного индустриального парка действуют успешные проекты, в том числе с ориентацией на использование зелёных технологий. Высокотехнологичные производства также будут развивать и в ТОР «Комсо- 
мольск»: в индустриальном парке на площадке «Парус» планируется производство воздушных судов и оборудования для авиационной техники.

Особое значение в реализации концептуальных положений модели $3 Э$ придаётся развитию устойчивого сельского хозяйства, включая органическое сельское хозяйство. Органическое сельское хозяйство вошло в число ведущих трендов прогноза научно-технологического развития агропромышленного комплекса Российской Федерации на период до 2030 г. В Хабаровском крае этот вид хозяйственной деятельности развивается в сложных природноклиматических условиях. Большая часть территории края относится к зоне рискованного земледелия, требующего инновационных подходов в достижении запланированных результатов. В качестве одного из приоритетных направлений совершенствования растениеводства края на перспективу определено развитие тепличного овощеводства [19]. И уже есть успешно реализованный проект в этом направлении: на территории индустриального парка «Авангард» функционирует тепличный комплекс для круглогодичного производства овощной продукции. Тепличный комплекс «Джей Джи Си Эвергрин» построен по голландским технологиям и занимается выращиванием овощей в специальном субстрате без применения пестицидов. Несмотря на более высокую цену, органические овощи пользуются спросом, а, следовательно, есть потенциал для дальнейшего развития в крае. Основными проблемами, тормозящими развитие органического сельского хозяйства в регионе, являются отсутствие законодательной базы, регулирующего данное направление сельского хозяйства, а также высокая стоимость «зелёного» производства и нехватка квалифицированных кадров.

Проблемы, связанные с переработкой и утилизацией отходов, являются наиболее приоритетными в модели $3 Э$ и одними из самых острых в крае. Именно поэтому проекты, ориентированные на развитие данного сектора, должны пользоваться особой поддержкой со стороны Правительства Российской Федерации. Между тем, только 9\% заявленных проектов в пределах ТОР Хабаровского края направлены на утилизацию и переработку отходов. Один из крупных многообещающих проектов связанный с переработкой отходов реализуется в Комсомольске-на-Амуре. Резидент ТОР «Комсомольск» ООО «ТапирЭко» запустил линию по переработке использованных автомобильных покрышек в резиновую крошку, используемую для покрытия прогулочных и беговых дорожек, обустройства футбольных полей, изготовления резиновых изделий. Также есть возможность использовать полученную крошку и в асфальтовых дорожных покрытиях, но для этого требуется дополнительное оборудование, а, следовательно, и дополнительные инвестиции. Среди потребителей продукции пока только местные компании из Комсомольска-на-Амуре, Хабаровска и Южно-Сахалинска. В качестве сырья для переработки на предприятии используются автомобильные шины, несколько тыс. тонн которых хранятся на полигоне твёрдых бытовых отходов в Комсомольске-на-Амуре, а также на несанкционированных свалках города. Утилизация, переработка и вторичное использование отходов - это один из главнейших шагов на пути к 3Э. Но чтобы сделать сектор мусоропереработки высокодоходным, требуется коренная перестройка системы управления всеми видами отходов и создание благоприятных условий для зелёного финансирования. В перспективе на всех площадках ТОР необходимо переходить к планированию безотходных производственных циклов. 
Оценке вклада лесного сектора в развитие $3 Э$ в России уделяется сегодня недостаточное внимание [20]. Обширные неиспользуемые территории лесного фонда Хабаровского края создают ошибочное представление о неисчерпаемости лесных ресурсов. Процессы интенсивного освоения древесных ресурсов леса, неконтролируемые вырубки и лесные пожары в Хабаровском крае оказывают значительное негативное воздействие на лесные экосистемы. Поэтому вопрос о повышении эффективности использования лесных ресурсов в крае является как никогда актуальным. Одними из наиболее острых проблемам лесного комплекса Хабаровского края являются незавершённость ресурсных циклов и слабое использование отходов. Одним из вариантов решения этих проблемы может стать организация производства древесных пеллет из отходов лесопромышленных предприятий. Твёрдое биотопливо имеет множество преимуществ и является более экологичным по сравнению с традиционными видами топлива (эмиссия углекислого газа при сжигании на 10-50\% ниже). Топливные гранулы широко востребованы не только на внутреннем рынке, но также и в странах АТР, где государством поддерживается биоэнергетика, a, следовательно, есть широкий рынок сбыта. В пределах ТОР «Комсомольск» реализуется крупный стратегический проект по строительству Дальневосточного центра глубокой переработки древесины, обещающего стать крупнейшим на Дальнем Востоке лесоперерабатывающим центром. Сейчас в Амурске уже функционирует $\mathrm{AO}$ «Амурский промышленный центр» по глубокой переработке древесины, где планируется запуск производства высококачественных пеллет. На территории Свободного порта Ванино также запущен завод (ООО «Токинский лесопильный завод») по производству пиломатериала для экспорта готовой продукции в страны АТР, в котором в дальнейшем планируется строительство цеха по производству топливных пеллет. Сейчас в Хабаровском крае производится около 240 тыс. тонн древесных топливных гранул, и этот объем может быть значительно увеличен, в том числе благодаря деятельности резидентов ТОР.

Ключевое значение для экономики субъектов Дальнего Востока, как и для всей России имеет модернизация и изменение приоритетов энергетического сектора, который вносит самый большой вклад в загрязнение окружающей среды. О необходимости развивать альтернативную энергетику на Дальнем Востоке неоднократно отмечалось в государственных программах развития региона, при этом особенно важно развитие возобновляемых источников энергии в отдалённых, труднодоступных районах. При наличии соответствующего ресурсного потенциала не совсем понятно, почему эти инициативы так слабо реализуются на строящихся площадках ТОР. Так, например, рыбоперерабатывающие предприятия в ТОР «Николаевск», столкнулись с нехваткой энергомощности, однако вопрос о возможности использования альтернативных источников энергии не заявлен в программе развития. Но все же в Хабаровском крае есть успешные практики использования возобновляемых источников энергии (в большинстве случаев реализуемые по инициативе самих предпринимателей). На площадке «Авангард» в компания ООО «Энергоимпульс+», функционируют 5 ветрогенераторов, которые уже успели окупиться и позволить сэкономить на электроэнергии порядка 12 млн руб. Одной из проблем, при эксплуатации таких установок, является выработка излишка энергии, которую из-за несовершенства российского законодательства приходится бесплатно отдавать в сеть. 
Ещё одним ключевым сектором развития $3 Э$ является туристическая отрасль. Интенсификацию развития внутреннего туризма в Хабаровском крае, в первую очередь, связывают с модернизацией аэропорта (площадка «Аэропорт» ТОР «Хабаровск»), по завершении строительства которого ожидается увеличение пассажиропотока в г. Хабаровске и числа туристов в край. Кроме того, в рамках ТОР «Хабаровск» ведутся работы по улучшению туристической инфраструктуры: осуществляется реализация проекта по созданию современного гостиничного комплекса на стадионе имени Ленина в г. Хабаровске. Большие надежды возлагаются также на реализацию крупнейшего проекта в Хабаровском крае по развитию активного туризма. На площадке «Холдоми», входящей в ТОР «Комсомольск», работают 3 инвестора, осуществляющие строительство новых горнолыжных трасс, гостиницы повышенной комфортности, гондольной дороги и водно-оздоровительного комплекса. В результате модернизации появится более 15 дополнительных километров трасс разных уровней сложности. По данным Минвостокразвития, общая стоимость инвестиционного проекта составляет около 440 млрд руб. Останется ожидать увеличение туристического потока, но для этого потребуется решение проблем с транспортной логистикой для иностранных туристов.

Таким образом, в целом заявленные проекты в пределах ТОР Хабаровского края соответствуют приоритетным направлениям «зелёного» роста. Пока из всех запланированных проектов резидентов ТОР фактически реализованы лишь около $10 \%$. Приведённые примеры создаваемых производств на территории края позволяют сделать вывод о том, что попытки «озеленения» в большинстве случаев осуществляются по инициативе самих предпринимателей, в том числе иностранных инвесторов. Но важно понимать, что первая фаза перехода к $3 Э$ весьма далека от бизнеса в обычном понимании, а является периодом инвестирования колоссальных средств в надежде на будущие изменения [21]. И без существенной государственной поддержки и экологоориентированной региональной политики все попытки «озеленить» экономику края могут оказаться безуспешными.

\section{Выводы}

Короткий временной интервал создания и функционирования ТОР в пределах российского Дальнего Востока не позволяет сделать окончательные выводы относительно эффективности реализуемой политики. Но определённые тенденции уже имеют чёткие очертания как с позиции положительных, так и отрицательных моментов. В складывающейся территориально-отраслевой структуре ТОР ДФО в целом инвестиционной привлекательностью выделяются проекты, связанные с разработкой месторождений полезных ископаемых, обеспечивающие экспортные потоки в страны АТР. Для южных субъектов федерального округа попытки совершенствования территориально-отраслевой структуры хозяйства в направлении усиления значимости менее экологозатратных отраслей, способствуя, таким образом, ослаблению роли сырьевых, вполне успешны. Важнейшей составляющей позитивных результатов следует признать расширение спектра хозяйственной деятельности, появление новых видов, использование во многих проектах инновационных решений.

Проведённый анализ ситуации в отношении политики формирования ТОР в пределах Хабаровского края свидетельствует о расширении спектра производств по изготовлению готовой продукции, стремлении к совершенство- 
ванию функционирования ресурсных циклов, активизации деятельности в сфере услуг. Но, к сожалению, даже в проектах связанных с экологоориентированными отраслями, без внимания оставлены вопросы, требующие безотлагательного решения для региона. Например, использование возобновляемых энергетических ресурсов, несмотря на успешный мировой опыт и, самое главное, имеющийся их высокий потенциал в крае, а также производство экологически чистой сельскохозяйственной продукции и рециклирование отходов. Многие имеющиеся резервы в крае также недоиспользованы, что отражено в низкой доле уже действующих предприятий.

Вызывают определённые опасения игнорирование в перспективных планах развития ТОР ориентиров «зелёного» аспекта, что не может не отразиться не только на экономических результатах в будущем, но и экологических. Приуроченность ТОР к уже освоенным зонам, со сложившимися экологическими проблемами, безусловно, осложнит экологическую обстановку в их пределах. Поэтому необходимо обращать внимание представителей бизнеса и региональных властей на использование «зелёных» технологий при строительстве новых объектов промышленности, а также отдавать предпочтение «зелёным» стандартам при организации индустриальных технопарков в рамках площадок ТОР. Очевидно, что для решения всего комплекса сложившихся проблем, модернизация не может быть точечной, а должна охватывать весь регион, а не только TOP. Но нужно же с чего-то начинать. Было бы совсем не лишним уже сейчас начать внедрять основные принципы мировой концепции устойчивости именно на этих территориях, отразив это как в региональных программах экономического развития, так и в экологической политике субъектов Дальнего Востока.

\section{Список источников / References}

1. О территориях опережающего социально-экономического развития в РФ. Федеральный закон РФ от 29 декабря 2014 г. № 473-Ф3. [O territoriyax operezhayushhego social no-e'konomicheskogo razvitiya $\mathrm{v}$ RF [On the territories of advanced social and economic development in the Russian Federation]. Federal Law of the Russian Federation of December 29, 2014 No. 473-Ф3. Available at: http://www.kremlin.ru/acts/bank/39279 (accessed 20.04.2018).

2. Официальный сайт Министерства Российской Федерации по развитию Дальнего Востока и Арктики. [Oficial`ny`j sajt Ministerstva Rossijskoj Federacii po razvitiyu Dal'nego Vostoka i Arktiki [Official website of the Ministry of the Russian Federation for the Development of the Far East and the Arctic]. Available at: https://minvr.ru/activity/territorii-operezhayushchego-razvitiya/

3. Заусаев В.К., Бурдакова Г.И., Кручак Н.А. Территории опережающего развития: работа над ошибками, ЭКО. Всероссийский экономический журнал, 2015, №2, сс. 76-86. [Zausayev V.K., Burdakova G.I., Kruchak N.A. Territorii operezhayushchego razvitiya: rabota nad oshibkami [Territories of the advancing development: correction of mistakes] EKO. Vserossijskij ekonomicheskij zhurnal = EKO. Russian economic magazine, 2015, no. 2, pp. 76-86.]

4. БИЗНЕС Online. [BIZNES Online [BUSINESS Online]. Available at: https://www.business-gazeta.ru/article/365442 (accessed 20.09.2018).

5. Глобальный «зеленый» новый курс: доклад UNEP / UNEP, 2009. 42 с. [Global "green" new course: report of UNEP, 2009. 42 p.] Available at: http://www.uncclearn. org/ sites/ www.uncclearn.org/ files/inventory/ UNEP90_RUS.pdf (accessed 30.11.2018).

6. The Road to Rio+20: For a Development-led Green Economy. Third issue / S. CullisSuzuki [et al.]. New York, Geneva, United Nation, 2012. 89 p. 
7. Working towards a Balanced and Inclusive Green Economy: A United Nations Systemwide Perspective. Prepared by the Environment Management Group (UNEMG), 2011. Available http://www.unemg.org/Portals/27/Documents/IMG/GreenEconomy/report/GreenEconomy -Full.pdf (accessed 20.12.2018).

8. Inclusive Green Growth: The Pathway to Sustainable Development. - Washington, D.C., World Bank, 2012. 192 p.

9. Навстречу «зеленой» экономике: пути к устойчивому развитию и искоренению бедности - обобщающий доклад для представителей властных структур. Программа ООН по окружающей среде. ЮНЕП, 2011. 43 с. [Towards "green" economy: ways to sustainable development and eradication of poverty - the generalizing report for representatives of power structures. The Program of the UN for the environment]. Available at: http://www.unep.org/greeneconomy/ Portals/88/documents/ger/GER_synthesis_ru.pdf (accessed: 20.02.2019).

10. Джексон Т. Процветание без роста. Экономика для планеты с ограниченными ресурсами. Москва, АСТ-ПРЕСС КНИГА, 2013. 304 с. [Dzhekson T. Procvetanie bez rosta. Jekonomika dlja planety $\mathrm{s}$ ogranichennymi resursami [Prosperity without Growth: Economics for a Finite Planet]. Moscow, AST-PRESS KNIGA Publ., 2013. 304 p.]

11. International Food Policy Research Institute. 2018 Global Food Policy Report. Washington, DC, International Food Policy Research Institute, 2018. https://doi.org/10.2499/9780896292970 Available at: http://ebrary.ifpri.org/utils/getfile/collection/p15738coll2/id/132273/filename/132488.pdf( accessed 10.04.2019).

12. Chalmin P., Gaillochet C. From Waste to Resource: An Abstract of World Waste Survey. Veolia Environmental Services, Edition Economica, 2009. 25 p.

13. World energy outlook 2018: summery OECD/IEA, 2018. 11 p. Available at: https://webstore.iea.org/download/summary/190?fileName=English-WEO-2018-ES.pdf (accessed 20.03.2019).

14. Видение - 2050. Новая повестка дня для бизнеса. [Videnie - 2050. Novaya povestka dnya dlya biznesa [Vision - 2050. A new agenda for business]. Available at: www.wbcsd.org/web/vision2050.htm (accessed 22.11.2018).

15. Массеров Д.А. Сущность и особенности реализации концепции «зеленой» экономики в условиях России. Менеджмент качества и устойчивое развитие в изменяющемся мире. Материалы Всероссийской научно-практической конференции с международным участием. ФГБОУ ВПО «Мордовский государственный университет им. Н.П. Огарева», 2016, сс. 195-199. [Masserov D.A. Sushchnost' і osobennosti realizacii koncepcii «zelenoj» ekonomiki v usloviyah Rossii [Essence and features of implementation of the concept of "green" economy in the conditions of Russia]. Quality management and sustainable development in the changing world. Materials of the AllRussian scientific and practical conference with the international participation. FGBOU VPO "Mordovian state university of N.P. Ogarev", 2016, pp. 195-199.]

16. Бобылев С.Н. Устойчивое развитие в интересах будущих поколений: экономические приоритеты. Мир новой экономики, 2017, №3, сc. 90-96. [Bobylev S.N. Ustojchivoe razvitie v interesah budushchih pokolenij: ehkonomicheskie prioritety [Sustainable development in the interests of future generations: economic priorities]. Mir novoj ehkonomiki =World of New Economy, no. 3, 90-96.]

17. Мирзеханова 3.Г. Экологические аспекты современного развития дальневосточных регионов в формате модели «зеленой экономики». Региональная экономика: теория и практика, 2018, т. 16, вып. 6, сс.1082-1096. [Mirzekhanova Z.G. Ekologicheskie aspekty sovremennogo razvitiya dal'nevostochnyh regionov v formate modeli «zelenoj ehkonomiki» [Environmental aspects of the modern development of the Far Eastern re- 
gions in the format of a model of "green economy]. Regional'naya ekonomika: teoriya $i$ praktika=Regional economy: theory and practice, 2018, vol. 16, issue 6., pp. 1082-1096.]

18. Минакир П.А. Ожидания и реалии политики «поворота на Восток». Экономика региона, 2017, т. 13, вып. 4., сс. 1016-1029. [Minaker P.A. Ozhidaniya i realii politiki «povorota na Vostok» [Expectations and realities of the policy of "turning to the East"]. Ekonomika regiona = Economy of the region, vol. 13, issue 4, pp. 1016-1029.]

19. Ким Л.В., Вдовенко А.В., Назарова А.А., Современное состояние и перспективы производства продукции растениеводства в Хабаровском крае. Дальневосточный аграрный вестник, 2017, №1 (41), сc. 104-113. [Kim L. In, Vdovenko A.V., Nazarova A.A., Sovremennoe sostoyanie i perspektivy proizvodstva produkcii rastenievodstva $\mathrm{v}$ Habarovskom krae [The current state and the prospects of production of crop production in Khabarovsk Krai] Dal'nevostochnyj agrarnyj vestnik = The Far East agrarian bulletin. 2017, no. 1 (41), pp. 104-113.]

20. Князева Г.А., Кирушева Н.Ю. Переход к «Зеленой» экономике на примере инновационного развития регионального лесного комплекса. Вестник СПбГУ. Серия 5: Экономика, 2016, №2. сc. 119-145 [Knyazeva G.A., Kirusheva N.U. Perekhod k «Zelenoj» ekonomike na primere innovacionnogo razvitiya regional'nogo lesnogo kompleksa [ Transition to "Green" economy on the example of innovative development of a regional forest complex] Vestnik $S P b G U=$ Messenger of St. Petersburg State University. Series 5: Economy, 2016, no. 2, pp.119-145.]

21. Крюков В. А. О соотношении «шансов» и «условий» становления «зеленой» экономики в природо-ресурсных регионах востока России. Восточный вектор России: шанс для «зеленой» экономики в природно-ресурсных регионах. Материалы научного семинара (оз. Байкал, Малое море, 27 июля - 1 августа 2015 г.) - Иркутск: Изд-во Ин-та географии им. В. Б. Сочавы СО РАН, 2016. 18. [Kryukov V. А. О sootnoshenii "shansov" i "uslovij" stanovleniya "zelenoj» ekonomiki v prirodo-resursnyh regionah vostoka Rossii// Vostochnyj vektor Rossii: shans dlya «zelenoj» ekonomiki v prirodno-resursnyh regionah [About a ratio of "chances" and "conditions" of formation of "green" economy in nature-resource regions of the East of Russia] Materialy nauchnogo seminara (oz. Bajkal, Maloe more, 27 iyulya - 1 avgusta 2015 g.) - Irkutsk: Izd-vo In-ta geografii im. V. B. Sochavy SO RAN, 2016 [East vector of Russia: chance for "green" economy in natural and resource regions. Materials of a scientific seminar (the Lake Baikal, Small Sea Strait, on July 27 - on August 1, 2015)].

\section{Сведения об авторах / About authors}

Мирзеханова Зоя Гавриловна, доктор географических наук, профессор, ведущий научный сотрудник, Институт водных и экологических проблем ДВО РАН. 680000 Россия, г. Хабаровск, Дикопольцева 56. E-mail: lorp@ivep.as.khb.ru

Zoya G. Mirzekhanova, Doctor of Geographic Sciences, Professor, Leading scientist of the Laboratory Optimization of Regional Environmental Management, Institute of Water and Ecology Problems, Far Eastern Branch, Russian Academy of Science. 56, Dikopolteva Street, Khabarovsk, Russia 680000.

E-mail:lorp@ivep.as.khb.ru

Кольцова Анастасия Алексеевна, кандидат географических наук, младший научный сотрудник, Институт водных и экологических проблем ДВО РАН. 680000 Россия, г. Хабаровск, Дикопольцева 56. E-mail: never_give_up@mail.ru

Anastasiya A. Koltsova, Candidate of Geographic Sciences, Scientist of the Laboratory Optimization of Regional Environmental Management, Institute of Water and Ecology Problems, Far Eastern Branch, Russian Academy of Science Russian Federation. 56, Dikopolteva Street, Khabarovsk, Russia 680000. E-mail: never_give_up@mail.ru 